\title{
Spatial Interpolation on Rainfall Data over Peninsular Malaysia Using Ordinary Kriging
}

\author{
Suhaila Jamaludin ${ }^{a^{*}}$, Hanisah Suhaimia \\ ${ }^{a}$ Department of Mathematics, Faculty of Science, UniversitiTeknologi Malaysia, 81310 UTM Johor Bahru, Johor, Malaysia \\ *Corresponding author: suhailasj@utm.my
}

\section{Article history}

Received :21 January 2013

Received in revised form :

7 May 2013

Accepted :25 June 2013

\section{Graphical abstract}

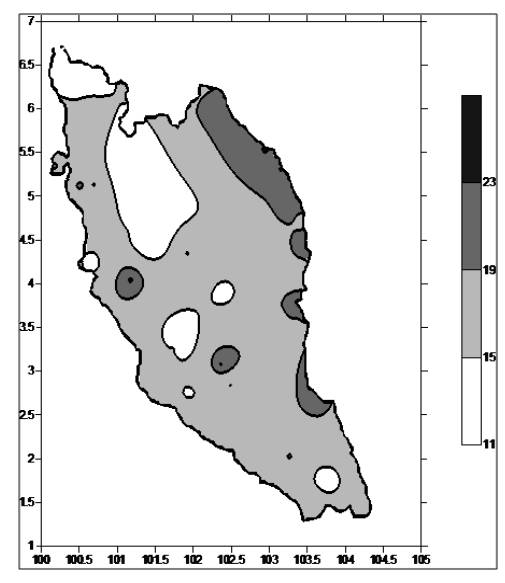

\begin{abstract}
This study presents the spatial analysis of the rainfall data over Peninsular Malaysia. 70 rainfall stations were utilized in this study. Due to the limited number of rainfall stations, the Ordinary Kriging method which is one of the techniques in Spatial Interpolation was used to estimate the values of the rainfall data and to map their spatial distribution. This spatial analysis was analysed according to the two indices that describe the wet events and another two indices that characterize dry conditions. Large areas at the east experienced high rainfall intensity compared to the areas in the west, northwest and southwest. The small value that has been obtained in Aridity Intensity Index (AII) reflects that the high amount of rainfall in the eastern areas is not contributed by low-intensity events (less than 25th percentile). In terms of number of consecutive dry days, Northwestern areas in Peninsular Malaysia recorded the highest value. This finding explains the occurrence of a large number of floods and soil erosions in the eastern areas.
\end{abstract}

Keywords: Ordinary kriging; spatial interpolation; rainfall; semivariogram rainfall indices

\section{Abstrak}

Kajian ini memaparkan analisis reruang bagi data hujan di Semenanjung Malaysia. Sebanyak 70 buah stesen hujan digunakan dalam kajian ini. Oleh kerana stesen hujan yang ada tidak mencukupi dan terhad, teknik Ordinary Kriging iaitu salah satu teknik dalam kaedah penganggaran ruang telah digunakan untuk menganggarkan nilai data hujan dan seterusnya memetakannya. Analisis reruang telah dijalankan berdasarkan kepada dua indeks yang menerangkan tentang kejadian hari basah dan dua lagi indeks yang mewakili kondisi kejadian hari kering. Hampir sebahagian besar kawasan di timur semenanjung mengalami kelebatan hujan yang tinggi berbanding dengan kawasan di barat, timur laut dan barat daya. Nilai yang kecil yang diperoleh dalam Aridity Intensity Index (AII) menggambarkan bahawa jumlah hujan yang tinggi di kawasan timur bukan disumbangkan oleh kejadian kelebatan hujan di tahap rendah (kurang daripada persentil ke-25). Dari aspek bilangan hari kering berlanjutan, kawasan di Barat Daya Semenanjung Malaysia mencatatkan nilai yang paling tinggi. Penemuan ini dapat menjelaskan tentang kejadian banjir besar dan juga hakisan tanah yang kerap berlaku di timur Semenanjung Malaysia.

Kata kunci: Ordinary kriging; penganggaran reruang; hujan; semivariogram; indeks hujan

(C) 2013 Penerbit UTM Press. All rights reserved.

\subsection{INTRODUCTION}

Effective and good rainfall data is vital in many human systems. It is important in hydrological analysis and also in the management of water resources. In Malaysia, an important issue with regards to the rainfall data records is the absence of rain gauge stations in particular regions. This is an important issue in hydrology because hydrologist utilizes the rainfall data as the input in most of their researches. Due to high cost and too many procedures that have been listed by World Meteorological Organization (WMO) in constructing rain gauge stations, it is quite impossible to solve this problem by constructing them in the regions involved in the research. Thus, it is important to estimate rainfall data in those unsampled locations. In order to estimate those data, spatial interpolation method is utilized. One of the spatial interpolation methods is Kriging.

Kriging technique is preferable because most of the researchers (e.g. $[1,2,3,4])$ identified that kriging can give a more accurate results for interpolation of daily rainfall data. There are many advantages of applying kriging technique. The benefits include it provides some measures of the certainty or accuracy of the predictions data, and also be able to produce a prediction surface. By using kriging method, the capability of obtaining high efficiency estimation in rainfall data is highly possible to be 
achieved. This is because it is able to identify locally intense storms which could lead to floods in particularly flash floods.

There are several types of kriging techniques appear in most of spatial interpolation of rainfall researches. They are simple, universal and ordinary kriging. Among these three types, ordinary kriging is more preferable. This is because, latest research regarding to analysis of rainfall by Grimes and PardoIgúzquiza[4] has concluded that ordinary kriging can give good results in order to estimate the rainfall data at unsampled locations. It is considered as the best method in terms of accuracy and bias. In order to estimate the value, ordinary kriging method concepts are reliable to be used. By using ordinary kriging method, daily rainfall data in unsampled locations at Peninsular Malaysia can be estimated. Besides, it is also reliable to be used when the numbers of rain gauge stations are limited.

\subsection{MATERIALS AND METHODS}

The rainfall data that has been used in this research was obtained from Malaysian Meteorological Department and Malaysia Department of Irrigation and Drainage. This research concentrated on the daily rainfall series from the period 1975 to 2007. Seventy rain gauge stations that are located in Peninsular Malaysia were selected for this study. The locations of those stations are as shown in Figure 1 and Table 1 shows the geographical coordinates of the stations. These rainfall stations are grouped according to their regions which are either west, east, northwest or southwest.

Table 1 The latitude and longitude of the rain gauges stations

\begin{tabular}{|c|c|c|c|c|}
\hline No. & Code & Station Name & Latitude & Longitude \\
\hline \multicolumn{5}{|c|}{ East } \\
\hline 1 & E01 & Kota Bharu & $6^{\circ} 10^{\prime}$ & $102^{\circ} 16^{\prime}$ \\
\hline 2 & E02 & To' Uban & $5^{\circ} 58^{\prime}$ & $102^{\circ} 08^{\prime}$ \\
\hline 3 & E03 & Sek. Keb. Kg. Jabi & $5^{\circ} 40^{\prime}$ & $102^{\circ} 33^{\prime}$ \\
\hline 4 & E04 & Kg. Merang, Setiu & $5^{\circ} 31^{\prime}$ & $102^{\circ} 57^{\prime}$ \\
\hline 5 & E05 & Stor JPS Kuala Trengganu & $5^{\circ} 19^{\prime}$ & $103^{\circ} 07^{\prime}$ \\
\hline 6 & E06 & Kg. Menerong & $4^{0} 56^{\prime}$ & $103^{\circ} 03^{\prime}$ \\
\hline 7 & E07 & $\begin{array}{ll}\text { KlinikBidan } & \text { Jambu } \\
\text { Bongkok } & \\
\end{array}$ & $4^{\circ} 56^{\prime}$ & $103^{\circ} 21^{\prime}$ \\
\hline 8 & E08 & $\begin{array}{l}\text { Sek.Men. Sultan Omar, } \\
\text { Dungun }\end{array}$ & $4^{\circ} 45^{\prime}$ & $103^{\circ} 25^{\prime}$ \\
\hline 9 & E09 & Sek. Keb. Kemasek & $4^{\circ} 25^{\prime}$ & $103^{\circ} 27^{\prime}$ \\
\hline 10 & E10 & JPS Kemaman & $4^{\circ} 13^{\prime}$ & $103^{\circ} 25^{\prime}$ \\
\hline 11 & E11 & Kuantan & $3^{\circ} 46^{\prime}$ & $103^{\circ} 13^{\prime}$ \\
\hline 12 & E12 & $\begin{array}{lll}\text { Rumah Pam } & \text { Pahang } \\
\text { Tua,Pekan } & & \\
\end{array}$ & $3^{\circ} 33^{\prime}$ & $103^{\circ} 21^{\prime}$ \\
\hline 13 & E13 & Endau & $2^{\circ} 35^{\prime}$ & $103^{\circ} 40^{\prime}$ \\
\hline 14 & E14 & Mersing & $2^{\circ} 27^{\prime}$ & $103^{\circ} 49^{\prime}$ \\
\hline \multicolumn{5}{|c|}{ Northwest } \\
\hline 15 & NW01 & Abi Kg. Bahru & $6^{\circ} 30^{\prime}$ & $100^{\circ} 10^{\prime}$ \\
\hline 16 & NW02 & Guar Nangka & $6^{\circ} 28^{\prime}$ & $100^{\circ} 16^{\prime}$ \\
\hline 17 & NW03 & Padang Katong ,Kangar & $6^{\circ} 27^{\prime}$ & $100^{\circ} 11^{\prime}$ \\
\hline 18 & NW04 & Arau & $6^{\circ} 25^{\prime}$ & $100^{\circ} 16^{\prime}$ \\
\hline 19 & NW05 & Kodiang & $6^{\circ} 22^{\prime}$ & $100^{\circ} 18^{\prime}$ \\
\hline 20 & NW06 & Alor Star & $6^{\circ} 12^{\prime}$ & $100^{\circ} 24^{\prime}$ \\
\hline 21 & NW07 & AmpangPedu & $6^{\circ} 14^{\prime}$ & $100^{\circ} 46^{\prime}$ \\
\hline
\end{tabular}

\begin{tabular}{|c|c|c|c|c|}
\hline 22 & NW08 & Pendang & $5^{\circ} 59^{\prime}$ & $100^{\circ} 28^{\prime}$ \\
\hline 23 & NW09 & SIK & $5^{\circ} 48^{\prime}$ & $100^{\circ} 43^{\prime}$ \\
\hline 24 & NW10 & Dispensari Kroh & $5^{\circ} 42^{\prime}$ & $101^{\circ} 00^{\prime}$ \\
\hline 25 & NW11 & Rumah Pam Bumbong Lima & $5^{\circ} 33^{\prime}$ & $100^{\circ} 26^{\prime}$ \\
\hline 26 & NW12 & Bkt Berapit & $5^{\circ} 22^{\prime}$ & $100^{\circ} 28^{\prime}$ \\
\hline 27 & NW13 & Ldg. Batu Kawan & $5^{\circ} 15$ & $100^{\circ} 25^{\prime}$ \\
\hline 28 & NW14 & KlinikBkt. Bendera & $5^{\circ} 25^{\prime}$ & $100^{\circ} 16^{\prime}$ \\
\hline 29 & NW15 & KolamTakongan Air Itam & $5^{\circ} 24$ & $100^{\circ} 16^{\prime}$ \\
\hline 30 & NW16 & Pintu A.Bagan,Air Itam & $5^{\circ} 21$ & $100^{\circ} 12^{\prime}$ \\
\hline 31 & NW17 & $\begin{array}{l}\text { Rumah Penjaga JPS. Parit } \\
\text { Nibong }\end{array}$ & $5^{\circ} 07^{\prime}$ & $100^{\circ} 30^{\prime}$ \\
\hline \multicolumn{5}{|c|}{ Southwest } \\
\hline 32 & SW01 & $\begin{array}{l}\text { Jam. Sg. Simpangn ,Jln. } \\
\text { Empat }\end{array}$ & $2^{\circ} 26^{\prime} 24^{\prime \prime} \mathrm{N}$ & $102^{\circ} 11^{\prime}$ \\
\hline 33 & SW02 & Malacca & $2^{\circ} 16^{\prime} 12^{\prime \prime} \mathrm{N}$ & $102^{\circ} 15^{\prime}$ \\
\hline 34 & SW03 & Pekan Merlimau & $2^{\circ} 09^{\prime} 00^{\prime \prime} \mathrm{N}$ & $102^{\circ} 25^{\prime}$ \\
\hline 35 & SW04 & Ldg. Bkt. Asahan & $2^{\circ} 23^{\prime} 24^{\prime \prime} \mathrm{N}$ & $102^{\circ} 33^{\prime}$ \\
\hline 36 & SW05 & Tangkak & $2^{\circ} 15^{\prime} 00^{\prime \prime} \mathrm{N}$ & $102^{\circ} 34^{\prime}$ \\
\hline 37 & SW06 & $\begin{array}{l}\text { Pintu Kawalan Separap Batu } \\
\text { Pahat }\end{array}$ & $1^{\circ} 55^{\prime} 12^{\prime \prime} \mathrm{N}$ & $102^{\circ} 52^{\prime}$ \\
\hline 38 & SW07 & Pintu Kawalan Sembrong & $1^{\circ} 52^{\prime} 48^{\prime \prime} \mathrm{N}$ & $103^{\circ} 03^{\prime}$ \\
\hline 39 & SW08 & $\begin{array}{l}\text { Sek.Men.Inggeris } \quad \text { Batu } \\
\text { Pahat }\end{array}$ & $1^{\circ} 52^{\prime} 12^{\prime \prime} \mathrm{N}$ & $102^{\circ} 58^{\prime}$ \\
\hline 40 & SW09 & Ldg. Kian Hoe , Kluang & $2^{\circ} 01^{\prime} 48^{\prime \prime} \mathrm{N}$ & $103^{\circ} 16^{\prime}$ \\
\hline 41 & SW10 & Kluang & $2^{\circ} 01^{\prime} 12^{\prime \prime} \mathrm{N}$ & $103^{\circ} 19^{\prime}$ \\
\hline 42 & SW11 & Ldg. Benut, Rengam & $1^{\circ} 50^{\prime} 24^{\prime \prime} \mathrm{N}$ & $103^{\circ} 21^{\prime}$ \\
\hline 43 & SW12 & $\begin{array}{l}\text { Ibu Bekalan Kahang , } \\
\text { Kluang }\end{array}$ & $2^{\circ} 13^{\prime} 48^{\prime \prime} \mathrm{N}$ & $103^{\circ} 36^{\prime}$ \\
\hline 44 & SW13 & $\begin{array}{l}\text { Sek.Men.Bkt Besar di Kota } \\
\text { Tinggi }\end{array}$ & $1^{\circ} 45^{\prime} 36^{\prime \prime} \mathrm{N}$ & $103^{\circ} 43^{\prime}$ \\
\hline 45 & SW14 & Senai & $1^{\circ} 37^{\prime} 48^{\prime \prime} \mathrm{N}$ & $103^{\circ} 40^{\prime}$ \\
\hline 46 & SW15 & Ldg. Getah Kukup, Pontian & $1^{\circ} 21^{\prime} 00^{\prime \prime} \mathrm{N}$ & $103^{\circ} 27^{\prime}$ \\
\hline 47 & SW16 & Stor JPS Johor Bahru & $1^{\circ} 28^{\prime} 12^{\prime \prime} \mathrm{N}$ & $103^{\circ} 45^{\prime}$ \\
\hline \multicolumn{5}{|c|}{ West } \\
\hline 48 & W01 & $\begin{array}{l}\text { Stn.Pemereksaan Hutan } \\
\text {,Lawin }\end{array}$ & $5^{\circ} 18^{\prime} 00^{\prime \prime} \mathrm{N}$ & $101^{\circ} 03^{\prime}$ \\
\hline 49 & W02 & Selama & $5^{\circ} 08^{\prime} 24^{\prime \prime} \mathrm{N}$ & $100^{\circ} 42^{\prime}$ \\
\hline 50 & W03 & Rumah JPS, AlorPongsu & $5^{\circ} 03^{\prime} 00^{\prime} \mathrm{N}$ & $100^{\circ} 35^{\prime}$ \\
\hline 51 & W04 & Pusat Kesihatan Bt.Kurau & $4^{\circ} 58^{\prime} 48^{\prime \prime} \mathrm{N}$ & $100^{\circ} 48^{\prime}$ \\
\hline 52 & W05 & Gua Musang & $4^{\circ} 52^{\prime} 48^{\prime \prime} \mathrm{N}$ & $101^{\circ} 58^{\prime}$ \\
\hline 53 & W06 & Ipoh & $4^{\circ} 34^{\prime} 12^{\prime \prime} \mathrm{N}$ & $101^{\circ} 06^{\prime}$ \\
\hline 54 & W07 & Ldg Boh & $4^{\circ} 27^{\prime} 00^{\prime \prime} \mathrm{N}$ & $101^{\circ} 25^{\prime}$ \\
\hline 55 & W08 & S. K. Kg. Aur Gading & $4^{\circ} 21^{\prime} 00^{\prime \prime} \mathrm{N}$ & $101^{\circ} 55^{\prime}$ \\
\hline 56 & W09 & Sitiawan & $4^{\circ} 13^{\prime} 12^{\prime \prime} \mathrm{N}$ & $100^{\circ} 42^{\prime}$ \\
\hline 57 & W10 & $\begin{array}{l}\text { Rumah Kerajaan JPS,Chui } \\
\text { Chak }\end{array}$ & $4^{\circ} 03^{\prime} 00^{\prime \prime} \mathrm{N}$ & $101^{\circ} 10^{\prime}$ \\
\hline 58 & W11 & Rumah Pam Paya Kangsar & $3^{\circ} 54^{\prime} 00^{\prime \prime} \mathrm{N}$ & $102^{\circ} 25^{\prime}$ \\
\hline 59 & W12 & Ibu Bekalan Sg. Bernam & $3^{\circ} 42^{\prime} 00^{\prime \prime} \mathrm{N}$ & $101^{\circ} 21^{\prime}$ \\
\hline 60 & W13 & Kg. Sg. Tua & $3^{\circ} 16^{\prime} 12^{\prime \prime} \mathrm{N}$ & $101^{\circ} 41^{\prime}$ \\
\hline 61 & W14 & Gombak & $3^{\circ} 16^{\prime} 12^{\prime \prime} \mathrm{N}$ & $101^{\circ} 43^{\prime}$ \\
\hline 62 & W15 & Genting Kelang & $3^{\circ} 14^{\prime} 24^{\prime \prime} \mathrm{N}$ & $101^{\circ} 45^{\prime}$ \\
\hline 63 & W16 & JPS. Wilayah Persekutu & $3^{\circ} 09^{\prime} 36^{\prime \prime} \mathrm{N}$ & $101^{\circ} 40^{\prime}$ \\
\hline 64 & W17 & Genting Sempah & $3^{\circ} 22^{\prime} 12^{\prime \prime} \mathrm{N}$ & $101^{\circ} 46^{\prime}$ \\
\hline 65 & W18 & Janda Baik & $3^{\circ} 19^{\prime} 48^{\prime \prime} \mathrm{N}$ & $101^{\circ} 51^{\prime}$ \\
\hline 66 & W19 & Sg.Lui Halt & $3^{\circ} 04^{\prime} 48^{\prime \prime} \mathrm{N}$ & $102^{\circ} 22^{\prime}$ \\
\hline 67 & W20 & Ldg. Sg. Sabaling & $2^{\circ} 51^{\prime} 00^{\prime \prime} \mathrm{N}$ & $102^{\circ} 29^{\prime}$ \\
\hline 68 & W21 & Setor JPS Sikamat Seremban & $2^{\circ} 44^{\prime} 24^{\prime \prime} \mathrm{N}$ & $101^{\circ} 57^{\prime}$ \\
\hline 69 & W22 & Hospital Port Dickson & $2^{\circ} 31^{\prime} 48^{\prime \prime} \mathrm{N}$ & $101^{\circ} 48^{\prime}$ \\
\hline 70 & W23 & Ldg. Sengkang & $2^{\circ} 25^{\prime} 48^{\prime \prime} \mathrm{N}$ & $101^{\circ} 57^{\prime}$ \\
\hline
\end{tabular}




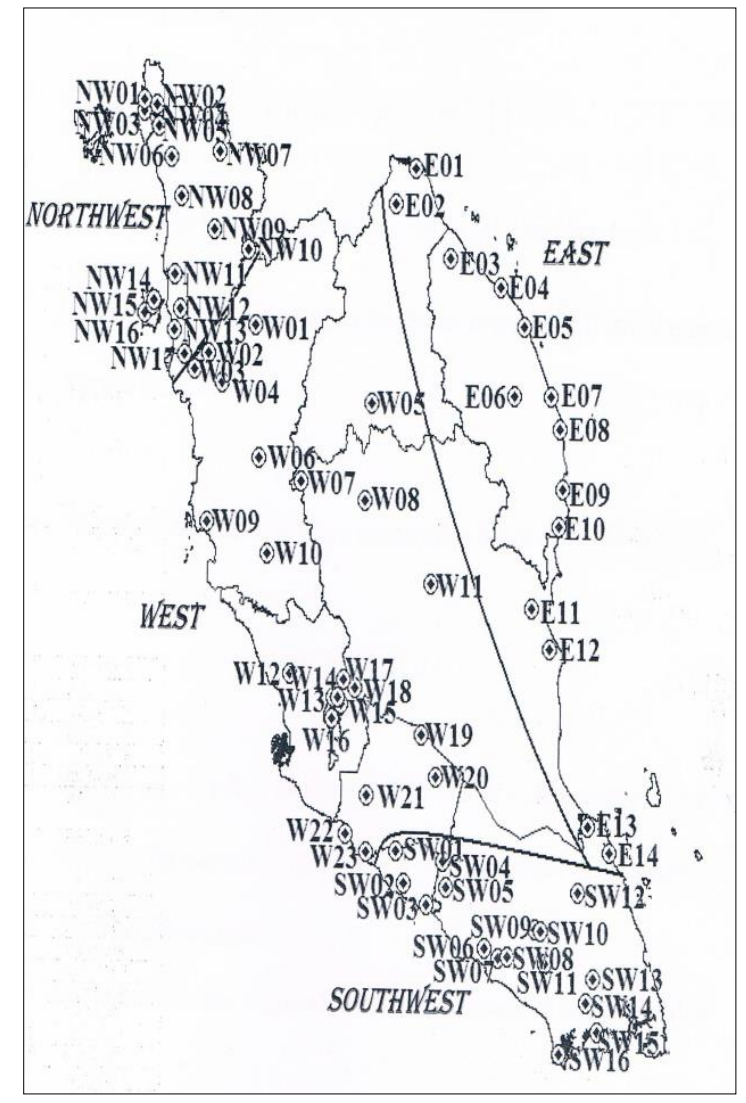

Figure 1 The locations of the rain gauges stations over Peninsular Malaysia

Table 2 Acronyms and explaination of the indices

\begin{tabular}{lll}
\hline \multicolumn{1}{c}{ Acronyms } & \multicolumn{1}{c}{ Explaination } & \multicolumn{1}{c}{ Units } \\
\hline SII & Simple Intensity Index & $\mathrm{mm} / \mathrm{day}$ \\
R95 & Number of days with daily precipitation totals exceeding the 95th percentile & days \\
CDD & Maximum number of consecutive dry days $(\mathrm{R}<1 \mathrm{~mm})$ & days \\
AII & Aridity Intensity Index & mm/day \\
\hline
\end{tabular}

The climate in Malaysia is governed by the Northeast and Southwest monsoons throughout the year. Climatologically, Northeast monsoon will contribute major rainy season to the east Peninsular Malaysia while the Southwest monsoon is a dry period for the whole country particularly to the western area [5]. With all these monsoons behavior, the variation of wet and dry days that also lead to the wet and dry spells should be studied.

So, there are only four rainfall indices that will be used in this study. Two indices (SII and R95) describe the wet conditions and another two indices (CDD and AII) describe the dry events. The indices that are selected in this research are based on the indices recommended by Costa and Soares [6]. The indices are listed in the Table 2 above.

The SII which is Simple Intensity Index is defined as the ratio between the total rain on the wet days over a year and the number of wet days in a year. In this research, a wet day is defined as a day with at least $1 \mathrm{~mm}$ of rainfall ( $\mathrm{R} \geq 1 \mathrm{~mm}$ ). $\mathrm{R} 95$ is defined as the number of days with daily precipitation totals above or equal to the 95th percentile annually. This 95th percentile threshold is determined from the base period 1975 until 2007 that fits the study area.

CDD represents the maximum number of consecutive dry days. Dry day is a day with precipitation less than $1 \mathrm{~mm}(\mathrm{R}<1$ $\mathrm{mm})$. According to Tilya and Mhita [7], this threshold is utilized due to the assumption that rainfall less than this amount evaporated off directly. Another index that describes the dry event is AII. AII which is Aridity Intensity Index is defined as the average precipitation per dry day. For this index, the 25th percentile of the rainy days is determined. The values of the 25 th percentile for all the stations been observed are between 2 to 13 $\mathrm{mm}$. It is used as the threshold to indicate a dry day. So, AII is the ratio between the total rain on the dry day and the number of dry days. The dry day is a day with precipitation below or equal to 25th percentile threshold.

As been mentioned earlier, the method that has been utilized in estimating the value of rainfall data in unsampled locations was Ordinary Kriging method. The first step in the kriging is the computation of empirical semivariogram. The empirical semivariogram can be computed by using robust semivariogram estimator proposed by Cressie and Hawkins [8]. The estimator are increased to the fourth power and adjusted for bias. His robust estimator is computed as:

$$
\bar{\gamma}(\mathbf{h})=\left\{\frac{1}{\left.2]_{N}(\mathbf{h})\right]} \Sigma_{\mathbb{N}(\mathbf{h})} \mid \mathrm{Z}\left(\mathrm{s}_{\mathrm{l})}-\left.\mathrm{Z}\left(\mathrm{s}_{j}\right)\right|^{1 / 2}\right\}^{4} /(0.457+0.494 /|N(\mathbf{h})|)\right.
$$


The benefit of this robust estimator is that the effect of outliers is reduced without removing specific data points from a data set [9]. Thus, robust estimator is more preferable.

Two aspects are important in modeling empirical semivariogram which are the number of pairs of the measured points with distance $\mathbf{h}$ exceeds 30 and the distance been used must be $h<\mathrm{M} / 2$ where $\mathbf{M}$ is the maximum distance between the locations. This is because, in empirical semivariogram, the value of distance $\mathbf{h}$, tolerance values $T(\mathbf{h})$ and the number of distance $J$ need to be considered. The next step is fitting the theoretical semivariogram based on empirical semivariogram. There are several effects that variogram parameters have on ordinary Kriging which are sill, nugget and range. This spatial process is assumed isotropic. There are three theoretical isotropic models in term of the semivariogram and they are spherical, exponential, and Gaussian model.

Ordinary kriging is the method that will be used in order to find the values of $Z\left(s_{0}\right)$. Those values will be estimated by using the known data, $Z\left(s_{i}\right)$ It is based on the statistical relationship among the measured point. The general formula for the interpolator is formed as:

$$
\widehat{Z}\left(s_{0}\right)=\sum_{i=1}^{m} w_{i} Z\left(s_{i}\right)
$$

In ordinary kriging, the value of $\mu$ is assumed to be unknown and constant. The weights with sum of $1, \sum_{i=1}^{m} w_{i}=1$ are to guarantee uniform unbiasedness. The value of $w_{i}$ is an unknown weight for the measured value at the $i$ th location. This will contribute to the value of $\tilde{Z}\left(s_{0}\right)$ in equation (2).

\subsection{RESULTS AND DISCUSSION}

\subsection{Summary of Semivariogram}

Generally, the spatial process is assumed isotropic. The theoretical semivariogram models for every index can either be spherical, Gaussian or exponential model. The results for the semivariogram analysis are as below: In order to fit the semivariogram model, Weighted Least Square (WLS) method that had been suggested by Cressie [10] was implemented. The sum of square error is the value is the minimized criterion. From the equation, the parameters value of sill, nugget and range can be identified. Figure 2(a)-(d) shows the estimated and empirical semivariogram and their parameters for all indices respectively.

Table 3 Results for the semivariogram analysis

\begin{tabular}{|l|l|l|l|}
\hline \multicolumn{1}{|c|}{ Index } & \multicolumn{1}{|c|}{ Semivariogram } & Equation & Sum of Square Error \\
\hline SII & Spherical & $\gamma(h)=0.0048+0.0371\left(1.5 \frac{\hbar}{1.993}-0.5\left(\frac{\hbar}{1.99 a}\right)^{2}\right)$ & 0.01798 \\
\hline R95 & Gaussian & $\gamma(h)=0.00037+0.00052\left(1-\operatorname{eksp}\left(-\frac{h^{2}}{1.9 a 14^{2}}\right)\right)$ & $5.13 \times 10^{-06}$ \\
\hline CDD & Spherical & $\gamma(h)=0.0032+0.0580\left(1.5 \frac{\hbar}{1.2797}-0.5\left(\frac{\hbar}{1.2797}\right)^{a}\right)$ & 0.1515 \\
\hline AII & Exponential & $\gamma(h)=0.1105\left(1-\operatorname{eksp}\left(-\frac{\hbar}{0.3497}\right)\right)$ & 0.48334 \\
\hline
\end{tabular}

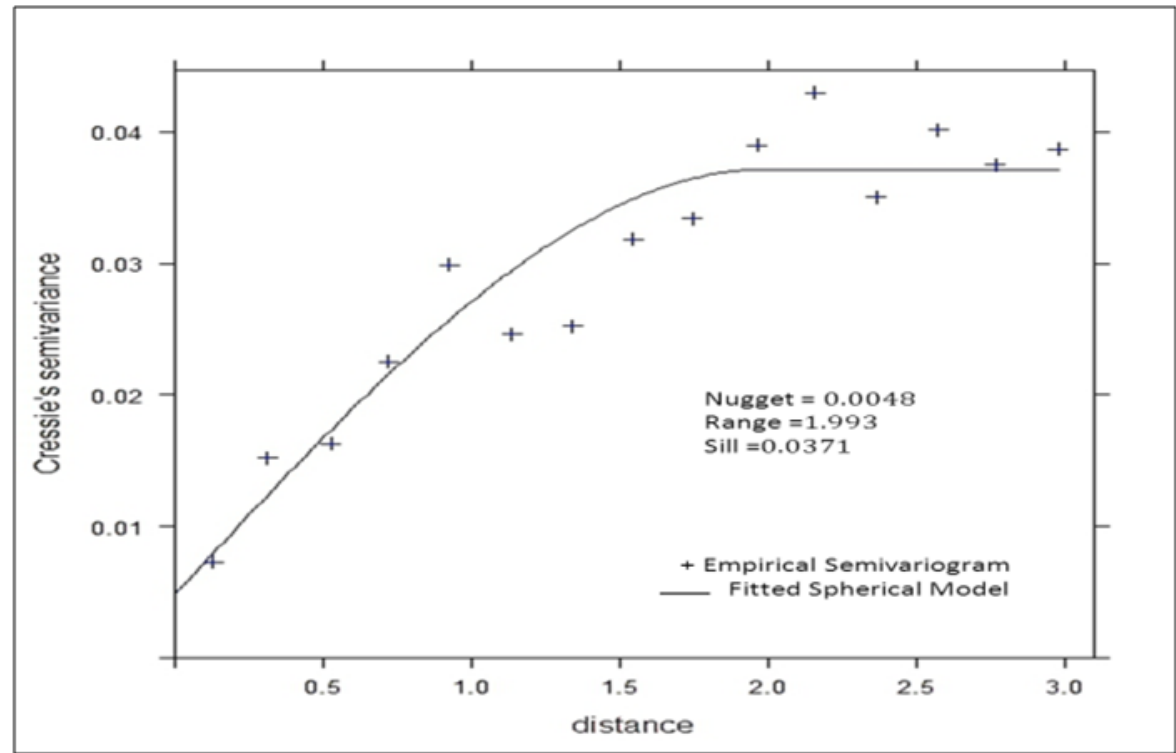




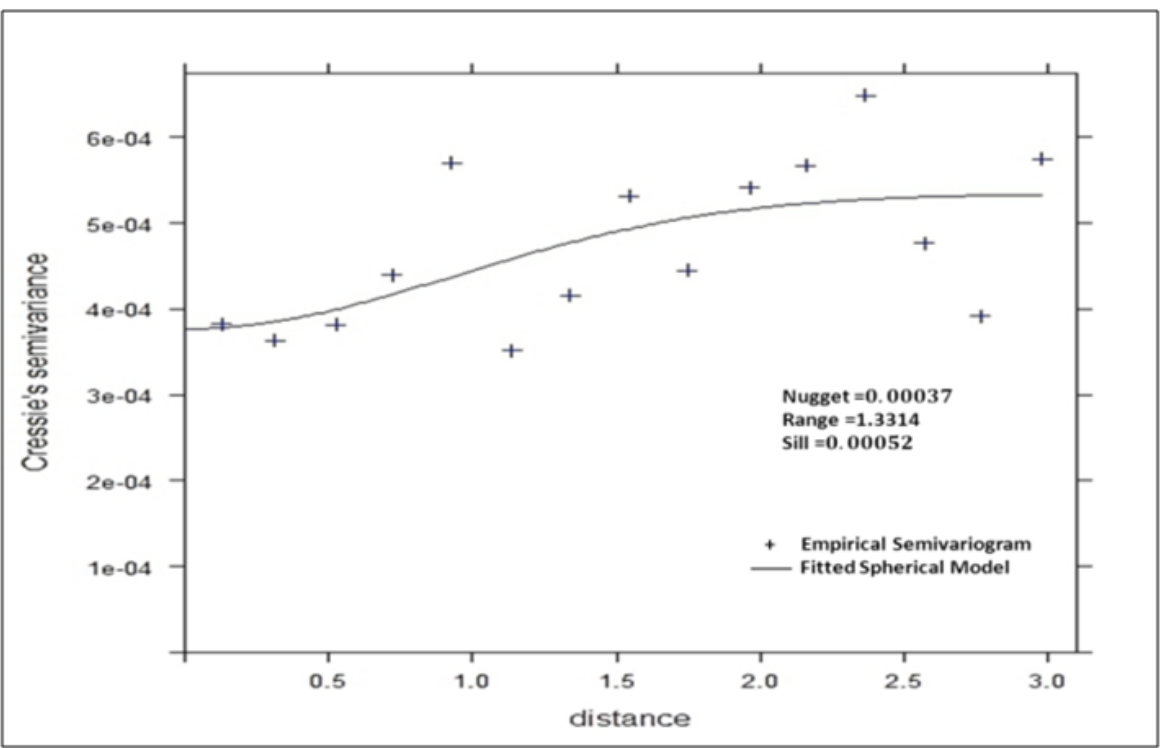

(b)

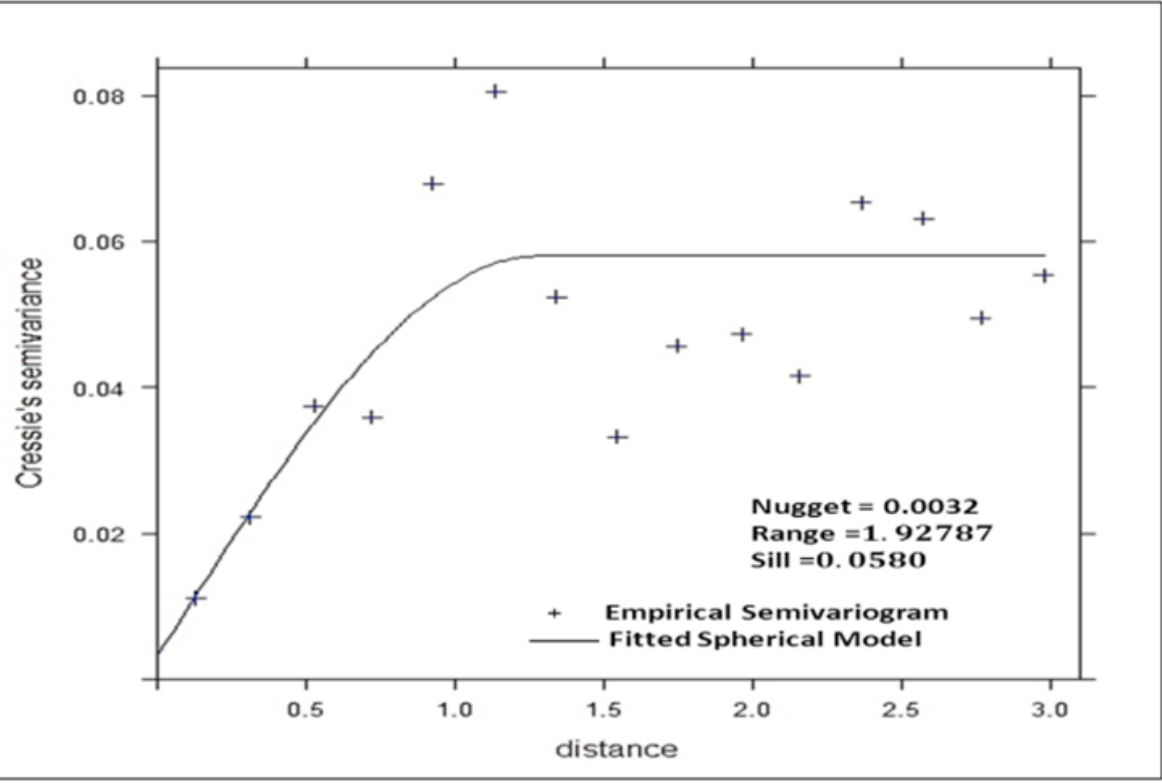

(c)

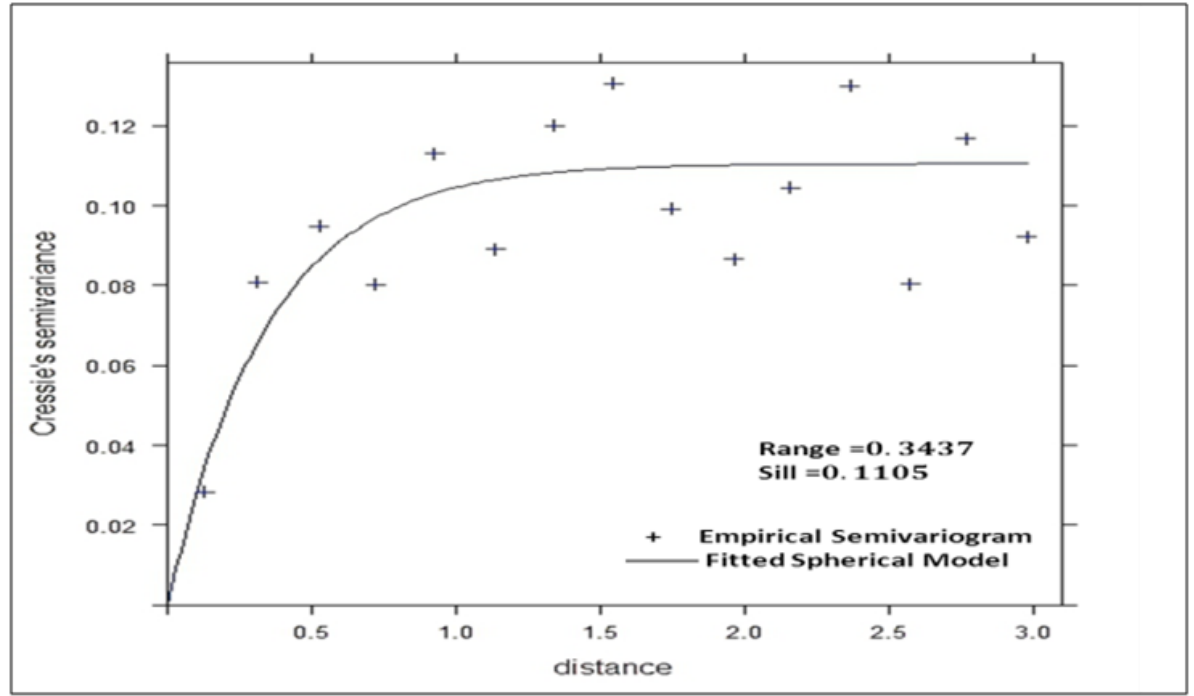

(d)

Figure 2 Empirical and theoritical semivariogram model: (a) SII (b) R95 (c) CDD (d) AII 


\subsection{Spatial Distribution of Rainfall Indices}

Isohyetal map for all the indices was produced by using Kriging technique. By using spatial interpolation method through Kriging technique, the rainfall index record at the unsampled locations can finally be estimated. There are 4900 estimated points that have been obtained through Kriging technique and all the values have been mapped over Peninsular Malaysia.

\subsubsection{Simple Intensity Index (SII)}

Figure 3 is the kriged map of Simple Intensity Index (SII) for 33 years. The stations that achieved the highest rainfall intensity are RumahKerajaan JPS Chui Chak, Sg.Lui Halt and Kg. Merang, Setiu. Both RumahKerajaan JPS Chui Chak and Sg.Lui Halt are the stations that are located in the west. The rainfall intensity at all these three stations exceeds $23 \mathrm{~mm} /$ day. The areas which are near to Rumah Kerajaan JPS Chui Chak and Sungai Lui Halt stations record the rainfall intensity between 19 to $23 \mathrm{~mm} /$ day.

The intensity at most of the eastern areas is between 19 to 23 $\mathrm{mm} /$ day which is quite high. This might be related with the northeast monsoon season that usually occurs around November until March. Suhaila [11] stated that the value of rainfall intensity in west, northwest, and southwest of Peninsular Malaysia getting less as the distance between the areas and the east coast increases. Besides, the Titiwangsa Range might block the northeasterly winds from bringing the heavy rainfall to those areas.

From Figure 3, it is clear that there were several areas that achieved the lowest intensity. Most of the areas are located in the west and southwest. These areas are considered as the driest areas since the rainfall intensity are between 11 to $15 \mathrm{~mm} / \mathrm{day}$. The lowest intensity is at Ladang Boh station which is $11.20 \mathrm{~mm} /$ day.

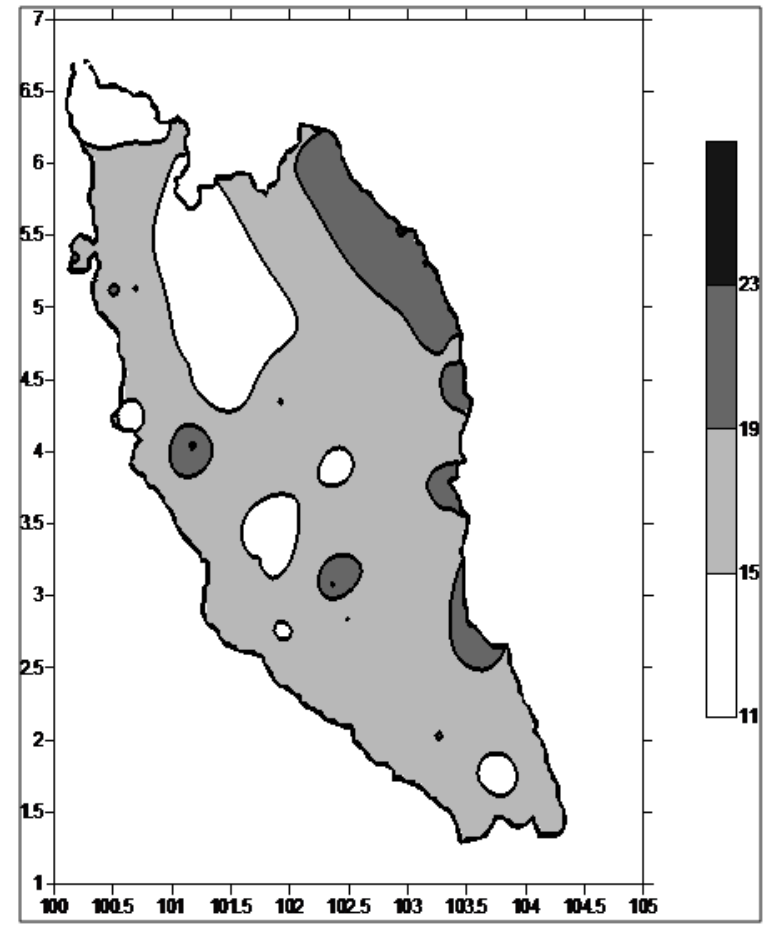

Figure 3 Isohyetal map of Kriging for SII (mm/day)

\subsubsection{R95 Index}

Events with rainfall values recorded beyond the 95th percentile are considered as high-intensity events. From the observation that has been done, the number of days for the occurrence of this high intensity event was quite uniform at all four regions. Sg. Lui Halt was recorded as the area that received more than $35.2 \mathrm{~mm}$ amount of rainfall a day for about 20 days. The region at latitude between 3.50 and $4.50 \mathrm{~N}$ in the western areas as shown in Figure 4.6 is the region that achieved high amount of precipitation total for about 19 days. This region included Rumah Kerajaan JPS Chui Chak and Ibu Bekalan Sg. Bernam stations. From the data obtained in SII, 93 rainy days per year was recorded at Sg. Lui Halt.

Among those 93 days, this high intensity event accounted for less than 20 days of total rainy days. LadangSengkang station has recorded the lowest number of days which is 17 days. Most of the areas in Peninsular Malaysia achieved uniform number of heavy rainy days which is for about 18 days. From the result obtained by Suhaila and Jemain [12] in their research regarding to the relative contribution of rainy days and amount of rain, they found out that the high-intensity events contributed less than $11 \%$ of total rainy days. However, these small percentages of rainy days contributed almost half of the total rain.

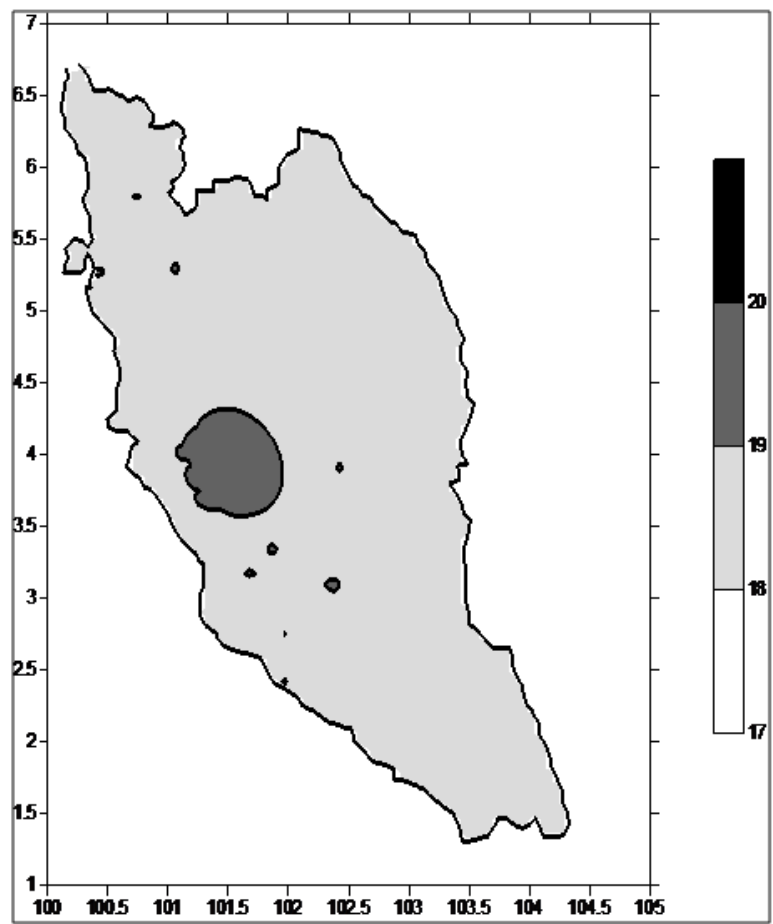

Figure 4 Isohyetal map of Kriging for R95 (days)

\subsubsection{CDD Index}

Figure 5 shows the isohyetal map of Kriging for CDD index. The areas in the northwest have recorded more than 32 consecutive dry days in a year. While other regions experienced shorter dry spell length with a maximum of less than 32 days. In the northeast areas, Guar Nangka station has recorded the highest value of maximum number of consecutive dry days which is 47 days. Other regions that located near to Ampang Pedu, Kodiang and Padang Katong Kangar also recorded highest number of days. 
Another two stripes denote the number of dry spells between 14 to 32 days. All of the areas in the western and eastern areas experienced shorter number of dry spells. The shortest is located at Pusat Kesihatan Bt. Kurau station which is only 14 days. This result was supported by Deni et al. [5], Dale [13] and Camerlengo [14]. All of them found that the northern areas are more prone to achieve longer number of dry spells than other parts of Peninsular Malaysia. From the figure, this might be related with the latitude of the areas which is the higher the latitude, the longer the number of dry days [14].

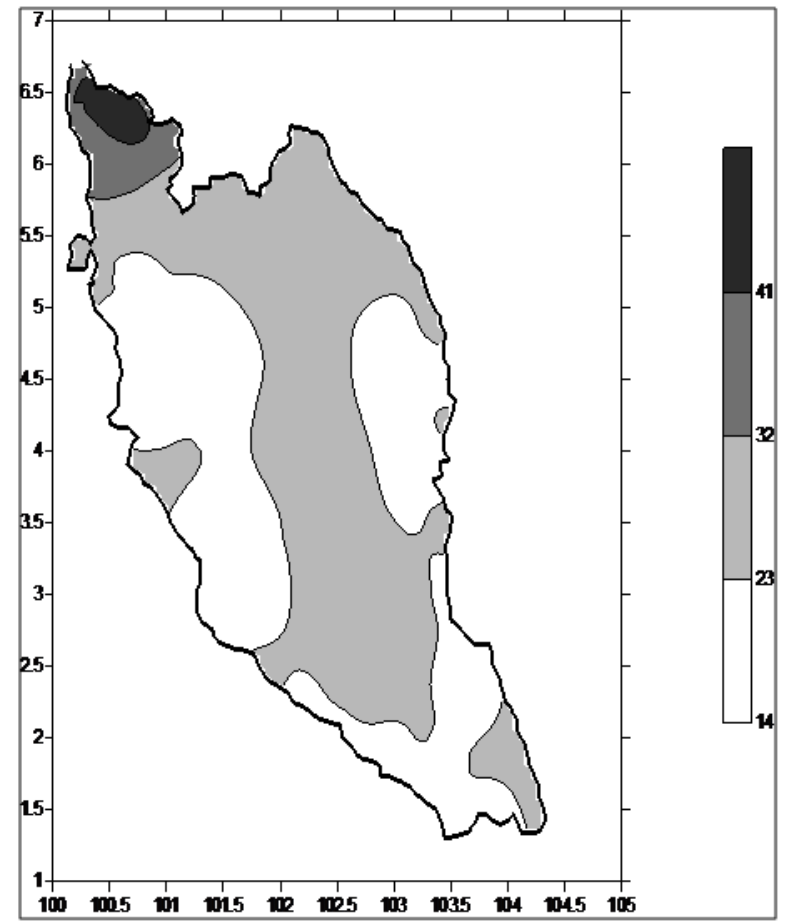

Figure 5 Isohyetal map of Kriging for CDD (days)

\subsubsection{Aridity Intensity Index (AII)}

Figure 6 shows the map of the estimated values for the Aridity Intensity Index (AII). From the figure, it was clearly shown that only a small spot in the map that has aridity intensity greater than $0.8 \mathrm{~mm} /$ day. It is located in the Chui Chak areas. This value indicates that this region received high rainfall amount in terms of low-intensity events (less than 25th percentile). As been mentioned in SII before, Chui Chak is one of the stations that achieved high rainfall intensity. This shows that the high amount of rainfall might be contributed most by this small threshold value. This was supported with the result obtained by Suhaila and Jemain [12]. They stated that the highest percentages of total rain that due to low-intensity events (less than 25th percentile) were mainly found in the areas of Chui Chak and Sg. Lui Halt stations in the west.

From Figure 6, most of the areas in Peninsular Malaysia have low aridity intensity which is between 0.2 to $0.5 \mathrm{~mm} / \mathrm{day}$. The driest regions are located near with Sitiawan station. The value recorded is between 0.2 to $0.25 \mathrm{~mm} / \mathrm{day}$. Some part of the regions in the north, east, south and west also recorded high level of dryness. From the results obtained, this situation relates much with the value of the 25 th percentile threshold. The small value of the 25 th percentile threshold indicates that in a day, small rainfall amount received by this region.
As been mentioned before in the SII, high intensity of rainfall was received by the eastern area. By comparing those two values, this situation indicates that the high rainfall amount in the east was probably contributed most by the extreme rainfall which is at the 95th percentile threshold and not this low-intensity event (less than 25th percentile). This might be due to the flow of the Northeast Monsoon that usually brings heavy rainfall to this area.

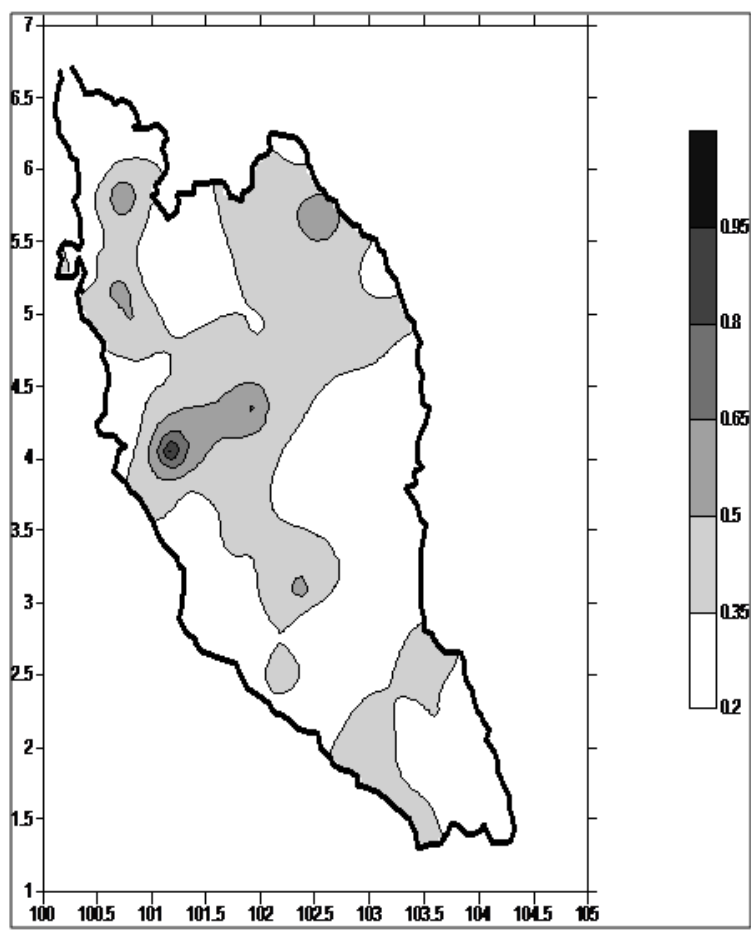

Figure 6 Isohyetal map of Kriging for AII (mm/day)

\subsection{CONCLUSION}

Much of the rainfall information in Peninsular Malaysia is based on annual data which is derived from daily rainfall recorded at individual stations. Due to the limited number of rainfall stations, kriging techniques were applied to estimate the rainfall values for areas where no rainfall stations exist. The results were then mapped over the Peninsula and provided information for studying the spatial behaviour of daily rainfall data. The spatial analysis of rainfall indices demonstrated different behaviours of rainfall patterns, particularly between the east, west, southwest and northwest.

From the analysis of the rainfall indices, it shows that all the four regions have different behaviour of rainfall patterns. Based on the analysis of Simple Intensity Index (SII), the highest rainfall intensity are at RumahKerajaan JPS Chui Chak, Sg.Lui Halt and $\mathrm{Kg}$. Merang, Setiu. However, other areas in the west recorded low average of rainfall intensity. High rainfall intensity was observed at most of the eastern areas. During the study period, the highest value that was recorded for R95 Index was 20 days. This large number of days was occurred at Sg. Lui Halt. Almost all the regions in Peninsular Malaysia achieved uniform number of heavy rainy days. The range was between 17 up to 20 days.

In terms of CDD Index, the map was clearly showed that the northwestern areas experienced greatest number of consecutive dry days. The highest value was recorded at Guar Nangka with the value reaching up 50 days. The spatial analysis of this rainfall index demonstrated different patterns particularly between the 
northeast and other three regions.Dried strips occurred mostly in the northeast regions. Aridity Intensity Index (AII) represents the ratio of the low-intensity events (less than 25th percentile) and the number of days. From the results obtained, the driest region occurred at Sitiawan area. Almost all areas in Peninsular Malaysia have small aridity intensity. Beside level of dryness, this index also can be related with the contributions of these low-intensity events to the amount of rainfall. The small value of the index indicates that these low-intensity events gave less contribution to the total rainfall amount at those areas.

From all the results, generally, almost all regions in the eastern areas experienced high rainfall intensity compared with the areas in the west, northwest and southwest. From the results in AII, it clearly explained that the high amount of rainfall in the eastern areas was not contributed by low-intensity events (less than 25th percentile). This finding explains the occurrence of a large number of floods and soil erosions in the eastern areas. In term of the number of dry days, greatest number of consecutive dry days occurred mostly at Northwestern areas in Peninsular Malaysia. As a conclusion, by using the Ordinary Kriging method, the rainfall data at the unsampled locations was estimated successfully.

\section{Acknowledgement}

The authors are indebted to the staff of the Drainage and Irrigation Department and the Malaysian Meteorological Department for providing the daily rainfall data used in this study. The comments of an anonymous referee are also acknowledged. The authors would like to extend their sincere gratitude to the Ministry of Higher Education Malaysia (MOHE) for the financial supports received for this work under (UTM-FRGS 4F024).We are also grateful to the Universiti Teknologi Malaysia for supporting the project.

\section{References}

[1] Buytaert, W., R. Celleri, P. Willems, B. D. Bievre, and G. Wyseure 2006. Spatial and Temporal Rainfall Variability in Mountainous Areas: A Case Study from the South Ecuadorian Andes. Journal of Hydrology. 329: 413-421.

[2] Cheng, K. S., Y. C. Lin, and J. J. Liou. 2007. Rain Gauge Network Evaluation and Augmentation Using Geostatistics. Hydrological Processes. 17: 1755-1769.

[3] Goovaerts, P. 2000. Geostatistical Approaches for Incorporating Elevation into the Spatial Interpolation of Rainfall. Journal of Hydrology. 228: 113-129.

[4] Grimes, D. I. F. and E. Pardo-Igúzquiza. 2010. Geostatistical Analysis of Rainfall. Geographical Analysis. 42: 136-160.

[5] Deni, S. M., A. A. Jemain and K. Ibrahim. 2008. The Spatial Distribution of Wet and Dry Spells over Peninsular Malaysia. Theor Appl. Climatol. 94: 163-173.

[6] Costa, A.C., J. Negreirosand A.Soares. 2009. Trends in Extreme Precipitation Indices Derived From a Daily Rainfall Database for the South of Portugal. International Journal of Climatology. 29: 19561975 .

[7] Tilya, F. F. and M. S. Mhita. 2007. Frequency of Wet and Dry Spells in Tanzania. Climate and Land Degradation. Springelink. 197-204.

[8] Cressie, N. A. C. 1989. Geostatistics. The American Statistician. 43(4): 197-202.

[9] Journel, A. G. and C. J. Huijbregts. 1978. Mining Geostatistics. London: Academic Press.

[10] Cressie, N. A. C. 1993. Statistics for Spatial Data. New York: John Wiley \& Sons.

[11] Suhaila, J. 2010. Analisis Amaun Hujan di Semenanjung Malaysia. Doctor Philosophy, Universiti Kebangsaan Malaysia.

[12] Suhaila, J. and A. A. Jemain. 2011. Spatial Analysis of Daily Rainfall Intensity and Concentration Index in Peninsular Malaysia.Theoretical and Applied Climatology.1-11

[13] Dale, W. L. 1960. The Rainfall of Malaya: Part II. J Trop Geog. 14: 1128.

[14] Camerlengo, A. L. 1999. Monthly Frequency Distributions of both Dry Spells and the Number of Days with Precipitation Greater than $25 \mathrm{~mm}$ over Peninsular Malaysia. GEOACTA. 23: 1-18. 